\title{
Preface: Special Issue on Stem Cells
}

Since the publication by James Thomson and colleagues at the University of Wisconsin about the first cultured human embryonic stem cells, there has been a groundswell of scientific activity to understand and leverage their potential in both the public and private sectors. The embryonic stem cells of Thomson's team were derived from excess donated embryos initially produced for in vitro fertilization (IVF). Thomson et al. demonstrated that the pluripotent stem cells they extracted from the human blastocysts can, in principle, be used to produce any cell in the body. If cells derived in this way prove to be optimal for the repair and regeneration of damaged or diseased tissues and can be applied to humans, then the discovery will be viewed by historians of medicine as a landmark in creating a new generation of regenerative therapies.

No sooner did stem cell science begin to attract converts from among cell and reproductive biologists than embryo research became the nation's premier moral issue in science. There was contentious debate within Congress over whether scientists should be engaged in research using embryos and that any medical intervention should only be used to save an embryo during gestation in the womb. Some scientists were diffident about using excess embryos and destroying them to acquire stem cells. Others tried to find an alternative. Bioethicists began reexamining various questions: What is a human life? What is the ethical status of an embryo? Does an extrauterine embryo have the same ethical status as an embryo developing in the uterus? How does research to develop therapeutic stem cells from embryos inform abortion politics? With the discovery of induced pluripotent stem cells, originally thought to be a source of pluripotent stem cells that would be "ethically uncontroversial," it is ironic that the debate about the value of human embryonic stem cells has sharpened rather than lessened. Questions also remain about the value of human embryonic stem cells when compared to existing sources of adult stem cells.

This issue is devoted to the ethics, politics, and social policies around stem cell research and their potential medical applications. The volume consists of 7 articles by different scholars, including scientists, philosophers, a religion scholar, and a lawyer, on a range of topics.

James Sherley is a biologist and adult stem cell researcher at the Adult Stem Cell Technology Center. He was also a plaintiff in the lawsuit Shirley v. Sebelius, which challenged the claim that a fertilized human egg was not a human life. His article addresses the core issue of when human life begins in the context of how we treat nascent forms of life.

Bertha Manninen, Associate Professor of Philosophy at Arizona State University, argues that using surplus human embryos for stem cell research is morally permissible. Her argument is grounded on the idea that, unlike human beings, blastocysts do not possess the property of individuality. Her essay explores the moral status of extrauterine embryos used for research. 
Lori Gruen is a professor of philosophy; feminist, gender, and sexuality studies; and environmental studies at Wesleyan University. Her essay examines the ethics of egg donation and compensation and the commercialization of oocytes in IVF and stem cell research. She argues against policies that prohibit compensating women for their eggs either for IVF or research.

Ronald Green, a professor of religion at Dartmouth College, explores the moral status of gametes derived from embryonic stem cells, the safety of new technology, and the effect of the new forms and outcomes of human reproductive technologies on children and families.

Susan Crockin is an adjunct professor of law at Georgetown Law School, and Celine Lefebvre is a third-year law student at Georgetown Law School. Their article critically examines the concepts of fertilization, conception, and personhood. Informed by both law and biology, their analysis makes a critical distinction between fertilization and conception and provides insights into ongoing personhood initiatives that are redefining the legal and moral issues directing stem cell research and evolving reproductive technologies.

Paul J. Cummins is a philosophy doctoral candidate at the Graduate Center, City University of New York, and fellow at the Icahn School of Medicine at Mt. Sinai. His essay addresses the question of potentiality with respect to human embryonic stem cell research. He asks, "Of what ethical importance is it that a biological entity has the potential to become a person?" and "Which entities have this potential?" He applies the concept of "potentiality" to human embryonic stem cells and induced pluripotent stem cells, drawing important comparisons.

Douglas Sipp is a stem cell policy expert and operations manager of the Riken Center for Developmental Biology, Kobe, Japan. His article addresses the moral claims made by different stakeholder groups in the stem cell debates and explores how their ideologies have influenced the social marketing and commercialization of stem cell interventions.

This issue of the journal reaches across disciplinary lines, as do the issues the contributors address. The editors believe that we can all benefit by exploring the methods, arguments, literature, data, and conclusions from disciplines that inform the public and scientific debates on stem cells. This group of essays illustrate clearly and poignantly that science is embedded in culture and the two have a dialectical relationship, each affecting the other.

\section{Guest Editors:}

Sheldon Krimsky

Lenore Stern Professor of Humanities \& Social Sciences

Tufts University, Medford, MA

Carol Zicklin, Visiting Professor of Philosophy

Brooklyn College, CUNY, Brooklyn, NY 
Preface: Introduction to the Special Section on Stem Cells

Jonathan Garlick

Professor; Department of Oral \& Maxillofacial Pathology; School of Dental Medicine Director; Division of Cancer Biology \& Tissue Engineering; School of Medicine

Director; Center for Integrated Tissue Engineering; School of Engineering

Tufts University, Medford, MA 